\title{
Analysis of Organic Photovoltaic Device at Different Series Resistances
}

\author{
Nikhil Rastogi ${ }^{1, *}$, Narender Singh $^{1}$, Sandeep Saxena ${ }^{2}$ \\ ${ }^{1}$ Department of Physics, IFTM University, Moradabad, India \\ ${ }^{2}$ Department of Physics, Bareilly College, Bareilly, India
}

Copyright $\bigcirc 2017$ by authors, all rights reserved. Authors agree that this article remains permanently open access under the terms of the Creative Commons Attribution License 4.0 International License

\begin{abstract}
GPVDM is simulation software that is used to analyze the optical and electrical properties of organic solar cell, based on P3HT: PCBM organic materials. The bulk hetero junction organic solar cell has been electrically simulated by GPVDM software at different series resistances. Organic bulk hetero junction solar cell is a mixture of P3HT and PCBM used as active layer material, ITO; a transparent electrode, PEDOT: PSS; an electron blocking layer and Al, back electrode. In this analysis, the electrical simulation has been done at different series resistances. It is observed that current density-voltage $(\mathrm{J}-\mathrm{V})$ characteristics are varied with the series resistance. The best $\mathrm{J}-\mathrm{V}$ characteristic as well as maximum short circuit current is obtained at $1 \Omega$ series resistance.
\end{abstract}

Keywords GPVDM Software, Series Resistance, Bulk Hetero Junction Organic Solar Cell

\section{Introduction}

Organic photo voltaic devices have attracted more attention in the last decade for its applications as flexible, renewable, non-conservative energy sources [1-3]. Organic solar cells are considered as promising renewable energy sources, which are alternative to the inorganic photo voltaic cell [4-5]. The advantages of organic solar cell are mechanical flexibility, lightweight, easy to fabrication at normal temperature and low cost fabrication. The performances of these devices are limited by the several factors. The charge mobility of the organic material is very low and due to the poor conductivity the efficiency is also very low. The highest power conversion efficiency of organic photo voltaic devices is based on bulk-hetero junction concept. Now a day's many solar cell technologies exist, in which organic solar cell is one of the newer classes of these technologies. Since the discovery of photo induced charge transfer between organic donors and acceptors, a great effort has been devoted to explore these materials for photo voltaic applications. Solar cell based on a bulk hetero junction (BHJ) of conjugate polymers P3HT (poly 3-hexylthiophene) and PCBM (phynyl- $\mathrm{C}_{70}$ butyric acid methyl ester) have been reported among the highest performing material and have been considered as the largest in researchers investigation and studies [6-9] for improving their power conversion efficiency [10-13]. The photo voltaic performance of the combination of P3HT and PCBM in organic blends has recently increased approaching $6 \%$ energy- conversion efficiency [14] and 6.1\% efficiency was achieved using PCDTBT and $\mathrm{PC}_{70} \mathrm{BM}$ blends. The main advantage of the $\mathrm{BHJ}$ solar cell is that most of the generated excitons reach a nearby donor - acceptor interface, where they associate into free charge carriers (electron and hole). These efficient excitons harvesting lead to higher power conversion efficiencies for BHJ solar cell. In BHJ photo voltaic device the series resistances Rs is a most important factor that affecting the $\mathrm{j}-\mathrm{v}$ characteristics of organic photo voltaic devices through decrease of solar efficiency and fill factor [15]. For large series resistance values, the short circuit current might decrease. A transparent electrode (ITO) and carriers transporting inter - layers of different kind could increase Rs significantly. Interfaces between the active layer material and inter layers (metallic contact) may well add more resistance in series because of partial energy level arrangement, which affects the best possible interface charge transfer. The overall effect of electronic transport mechanism is recognized to have impressive effect, when thick active layer films are used to increase light harvesting [16]. The thinner films are able to exhibit almost conversion of absorbed photon into collected carriers [17]. Thus indicating that transport mechanism do-not limit a realizable photo current [18-20], thicker active material layer devices suffer from an incomplete collection of photo-generated charges. It is also known that in real devices the analysis of the $\mathrm{j}-\mathrm{V}$ characteristics does not help in discriminating, in which the series mechanism is effectively dominating series resistance Rs. Therefore, the overall performance might be improved 
by librating operating mechanism involved in series resistance. In this work, electrical simulation of BHJ photovoltaic cell using GPVDM (general purpose photovoltaic device model) software at different series resistance is analyzed.

\section{Device Structure}

Bulk hetero junction is a mixture of two conjugate polymers of electron donor (P3HT) and electron acceptor molecules (PCBM) that allow absorption of light, generation of excitons, splitting of excitons at donor-acceptor interface, and systematic transport of positive and negative charges to opposite electrodes. The bulk hetero junction is mostly created by two conjugate polymers, casting and then allowing separating the two phases usually. The two conjugate polymers will self-assembled into an interpenetrating system connecting the two electrodes [21]. The advantage of BHJ structure is that most of the generated excitons reach a nearby donor-acceptor interface, where they dissociate into free charge carriers. The structure of bulk hetero junction solar cell is shown in figure 1 and 2 .
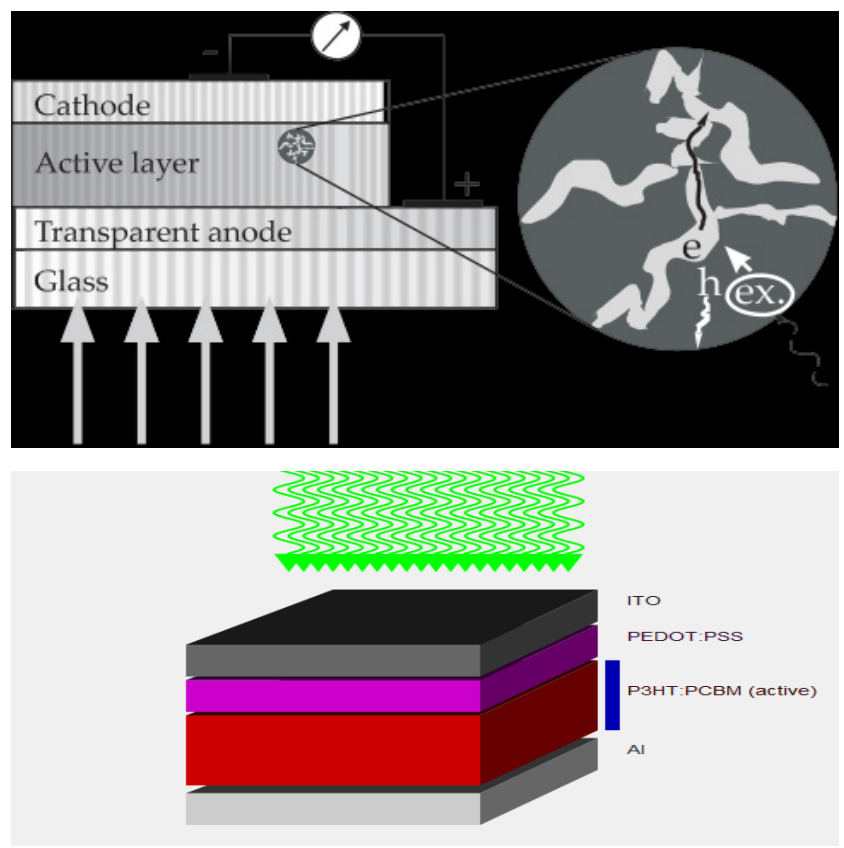

Figure1 and 2. Bulk Hetero junction solar cell

In bulk hetero junction solar cell, P3HT (3-hexyl thiophene) is a good electron donor material that transport positive holes and PCBM ([6, 6]-phenyl $\mathrm{C}_{71}$-butyric acid methyl ester) is a good electron acceptor material. It effectively transports electrons from molecule to molecule. The Indium Tin Oxide (ITO) film is used as a transparent electrode. Since, it has high transmittance in visible region and ability of conduction. The materials PEDOT: PSS or poly (3, 4-ethylenedioxy thiophene) poly (styrenesulfonate) is an electron blocking layer of work function $5.2 \mathrm{eV}$, used hole transporting layer and improve the work function of ITO layer. These may be used as buffer layers between the electrodes and active layer to block the electron and whole transfer in the wrong direction.

\section{Simulation}

The bulk hetero junction photo voltaic device is electrically simulated by the GPVDM software at different series resistance. This software is specially designed to simulate bulk hetero junction organic solar cells, such as those based on the P3HT: PCBM materials. The model contains both an electrical and optical properties, enabling current density-voltage characteristics [22]. The simulation of organic photo voltaic device can be separated into two parts, first electrical simulation and second optical simulation.

To describe the carrier (electron and hole) transport the bipolar drift-diffusion equations (1) \& (2) are solved in position space for electrons and holes. These are given as-

$$
\begin{gathered}
\mathrm{Jn}=\mathrm{q} \mu_{e} n_{f} \frac{\partial E_{L U M O}}{\partial x}+\mathrm{q} \operatorname{Dn} \frac{\partial n_{f}}{\partial x} \frac{\partial n_{f}}{\partial x} \\
\mathrm{Jp}=\mathrm{q} \mu_{p} p_{f} \frac{\partial E_{H O M O}}{\partial x}-\mathrm{q} \text { Dp } \frac{\partial p_{f}}{\partial x}
\end{gathered}
$$

Where $\mathrm{J}_{\mathrm{n}}$ and $\mathrm{J}_{\mathrm{p}}$ are the electron and hole current density, $\mu_{e}$ and $\mu_{p}$ are the electron and hole mobility, $\mathrm{n}_{\mathrm{f}}$ and $\mathrm{p}_{\mathrm{f}}$ are the concentration of electron and hole along the Fermi level and $\mathrm{E}_{\mathrm{LUMO}}$ and $\mathrm{E}_{\mathrm{HOMO}}$ be the energy of LUMO and HOMO level.

In this device model, there are two types of electrons (holes) i.e. free electrons (holes) and trapped electrons (holes). The free electrons (holes) have a finite mobility of $\mu_{e}^{o}\left(\mu_{h}^{o}\right)$ and trapped electrons (holes) cannot move at all and have a mobility of zero (23).

To calculate the average mobility, it is assumed to take the ratio of free to trapped carriers and multiply it by the free carrier mobility, which expressed in equation (3)

$$
\mu_{e}(n)=\frac{\mu_{e}^{o} n_{\text {free }}}{n_{\text {free }}+n_{\text {trap }}} \mu_{e}(n)=\frac{\mu_{e}^{o} n_{\text {free }}}{n_{\text {free }}+n_{\text {trap }}}
$$

Thus if all carriers were free the average mobility would be $\mu_{e}^{o}$ and if all carriers were trapped the average mobility would be zero. It should be noted that only $\mu_{e}^{o} \mu_{h}^{o}$ are used in the model for computation and $\mu_{\mathrm{e}}(\mathrm{n})$ is an output parameter. In organic solar cell photo-generated excitons are dissociated into electrons and holes at the donor-acceptor hetero junction. It is consider that the excitons dissociation probability at the hetero junction is high enough that excitons concentration at the donor - acceptor interface is zero. Thus, only the excitons generated with a distance of excitons diffusion length from the hetero junction can contribute to the photo- current generation.

The electrical simulation window is shown in figure 3. 


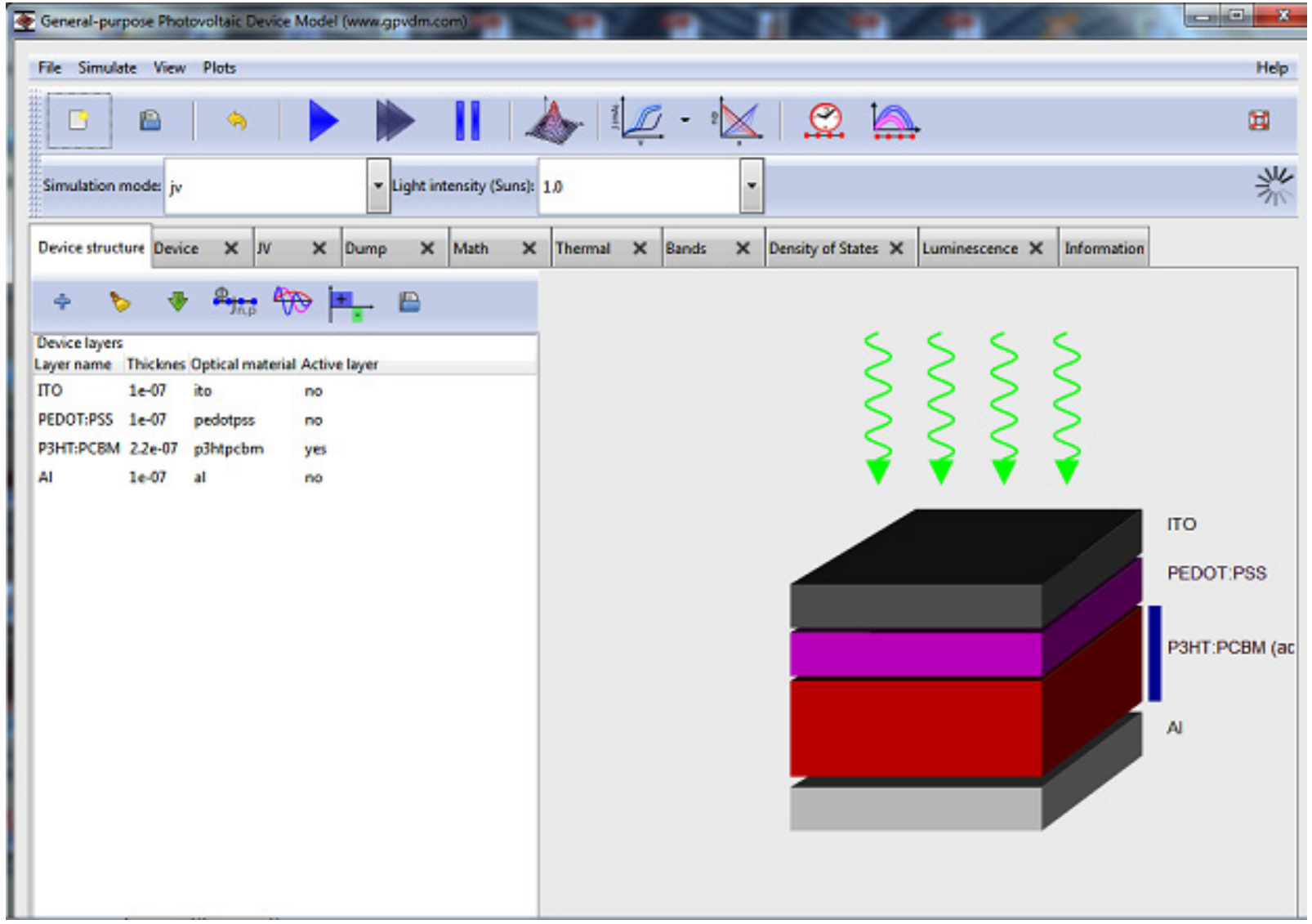

Figure 3. GPVDM Electrical Simulation window

\section{Characteristics of Organic Solar Cell:}

In order to determine the ability of an organic solar cell for conversion incident solar energy into electricity, the current voltage characteristics are measured both in dark and illumination. The current-voltage characteristic is shown in figure 4 .

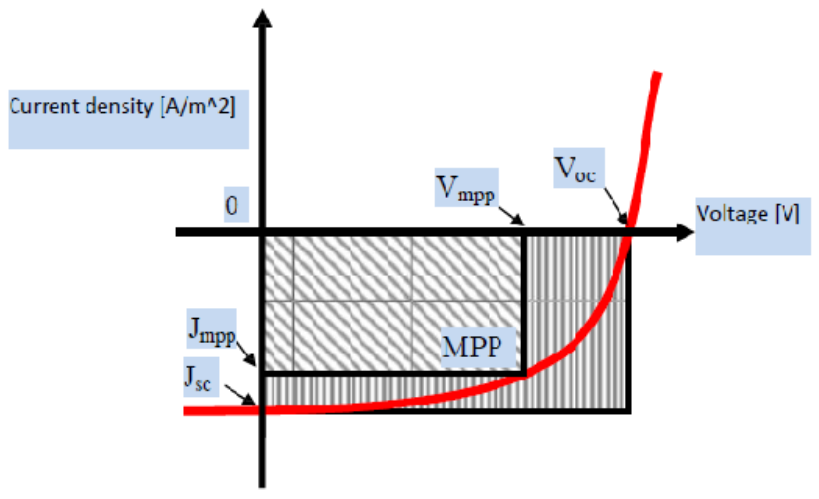

Figure 4. Current Voltage Characteristics

It is well known that in dark condition, solar cell ideally operate as a diode. Under illumination condition the device generates current. The short circuit current density $\left(\mathrm{J}_{\mathrm{sc}}\right)$ is zero under illumination at zero potential difference between anode and cathode. Under short circuit condition, the $\mathrm{J}_{\mathrm{sc}}$ is found at intersection of the curve and the open circuit voltage
$\left(\mathrm{V}_{\mathrm{oc}}\right)$ is the maximum voltage that can be generated by the organic solar cell. At open circuit voltage (Voc), short circuit current density ( Jsc) under illumination is zero and found where the curve intersects the horizontal axis. The maximum power point (MPP) is defined as the point where the product of current density and voltage, is maximum. The J-V curve gives the fill factor (FF) which is defined as the ratio between $\mathrm{P}_{\mathrm{MPP}}$ and the theoretically maximum power of the device $\left(\mathrm{P}_{\max }\right)$, expressed in equation (4)

$$
\mathrm{FF}=\frac{\operatorname{Vmax} \times J \max }{\operatorname{Voc} \times \mathrm{Jsc}} \frac{\operatorname{Vmax} \times \mathrm{Jmax}}{\operatorname{Voc} \times \mathrm{Jsc}}
$$

where $\mathrm{V}_{\max }$ and $\mathrm{P}_{\max }$, are the voltage and current density in the maximum power point respectively. The power conversion efficiency for a solar cell defined by the equation (5)

$$
\eta=\frac{\text { Pout }}{\text { Pin }}=\frac{F F \times \operatorname{Vmax} \times \mathrm{Jmax}}{\text { Pin }} \frac{F F \times \mathrm{Vmax} \times \mathrm{Jmax}}{\text { Pin }}
$$

where $\mathrm{P}_{\text {in }}$ is the power density of the light and $\mathrm{P}_{\text {out }}$ is the electric power generated by the bulk hetero junction solar device at maximum power point.

\section{Result and Discussion}

In this research work, the bulk hetero junction solar cell is designed by the GPVDM software to study the J-V characteristics at different series resistance. The simulation 
parameters are shown in table 1.

Table 1. Parameters for simulation

\begin{tabular}{|c|c|c|c|}
\hline $\begin{array}{l}\text { Sr. } \\
\text { No. }\end{array}$ & Parameters & $\begin{array}{c}\text { Parameter's } \\
\text { value }\end{array}$ & Units \\
\hline 1. & Electron trap density & $3.8 \times 10^{26}$ & $\mathrm{~m}^{-3} \mathrm{eV}^{-1}$ \\
\hline 2. & Hole trap density & $1.45 \times 10^{25}$ & $\mathrm{~m}^{-3} \mathrm{eV}^{-1}$ \\
\hline 3. & Electron mobility & $2.48 \times 10^{-7}$ & $\mathrm{~m}^{2} \mathrm{~V}^{-1} \mathrm{~s}^{-1}$ \\
\hline 4. & Hole mobility & $2.48 \times 10^{-7}$ & $\mathrm{~m}^{2} \mathrm{~V}^{-1} \mathrm{~s}^{-1}$ \\
\hline 5. & $\begin{array}{l}\text { Trapped electron to } \\
\text { free hole }\end{array}$ & $1.32 \times 10^{-22}$ & $\mathrm{~m}^{-2}$ \\
\hline 6. & $\begin{array}{c}\text { Trapped hole to free } \\
\text { electron }\end{array}$ & $4.67 \times 10^{-26}$ & $\mathrm{~m}^{-2}$ \\
\hline 7. & $\begin{array}{l}\text { Free electron to } \\
\text { trapped electron }\end{array}$ & $2.5 \times 10^{-20}$ & $\mathrm{~m}^{-2}$ \\
\hline 8. & $\begin{array}{c}\text { Free hole to trapped } \\
\text { hole }\end{array}$ & $4.86 \times 10^{-22}$ & $\mathrm{~m}^{-2}$ \\
\hline 9. & Temperature & 300 & $\mathrm{~K}$ \\
\hline 10. & Shunt Resistance & $1.9 \times 10^{5}$ & $\Omega$ \\
\hline 11. & Series Resistance & 19.5 & $\Omega$ \\
\hline 12. & $\begin{array}{l}\text { ITO ( electrode) } \\
\text { thickness }\end{array}$ & $1 \times 10^{-7}$ & M \\
\hline 13. & PEDOT:PSS & $1 \times 10^{-7}$ & $\mathrm{M}$ \\
\hline 14. & $\begin{array}{c}\text { Active layer } \\
\text { thickness }\end{array}$ & $2.2 \times 10^{-7}$ & M \\
\hline 15. & $\begin{array}{l}\mathrm{Al} \text { ( electrode) } \\
\text { thickness }\end{array}$ & $1 \times 10^{-7}$ & M \\
\hline 16. & Device width & 0.003464 & $\mathrm{M}$ \\
\hline 17. & Device breath & 0.003464 & M \\
\hline
\end{tabular}

The illumination $\mathrm{J}-\mathrm{V}$ characteristics are simulated at different resistances $1 \Omega, 3 \Omega, 5 \Omega$, and $7 \Omega$. The J-V characteristic curves are shown in the figure 5 . It is clear from the J-V characteristics curves that the short circuit current decrease with increase in the series resistance continuously, at $1 \Omega$ the short circuit current is maximum and minimum at $7 \Omega$. The active area makes the photo gene rated current travel a longer distance, before it is collected at the electrodes. The position of the contacts in the device causes current flow primarily in the $\mathrm{x}$-direction, so resistance should depend only on the length of the device. In the study, a thick grid will be applied to maintain a low effective resistance of the ITO even as the area of the solar cell becomes large.

As series resistance increases, the voltage drop between the junction voltage and the terminal voltage becomes greater for the same current. The result is that the current-controlled portion of the I-V curve begins to sag toward the origin, producing a significant decrease in the terminal voltage and a slight reduction in $I_{S C}$, the short circuit current. Very high values of $R_{S}$ will also produce a significant reduction in $I_{S C}$; in these regimes, series resistance dominates and the behavior of the solar cell resembles that of a resistor. These effects are shown for crystalline silicon solar cells in the j-v curves [24].

Current density - Applied voltage

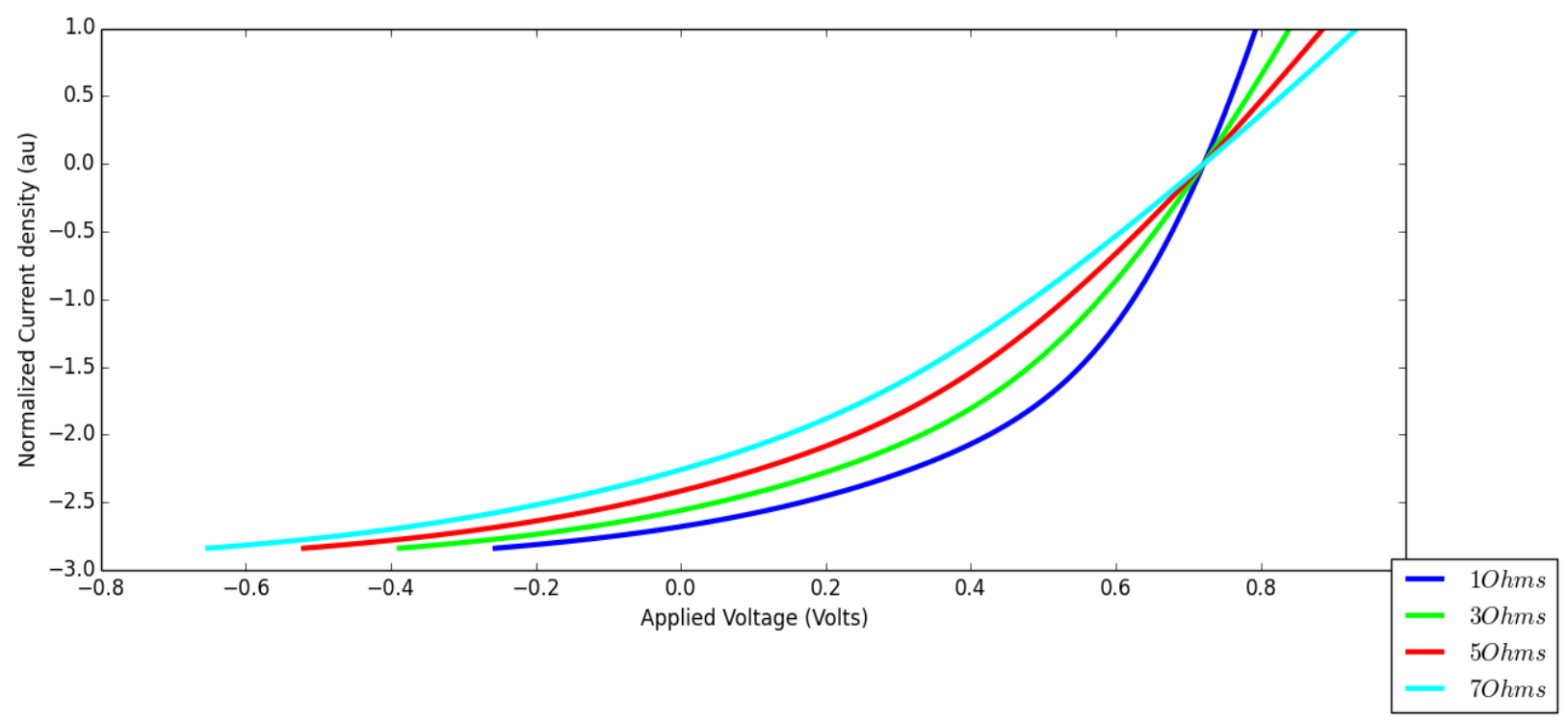

Figure 5. J-V characteristics at different series resistance $1 \Omega, 3 \Omega, 5 \Omega, 7 \Omega$ 


\section{Conclusions}

In this research study, the electrical simulation of P3HT: PCBM based bulk hetero junction solar cell is done. It is found that for different series resistances, the $\mathrm{J}-\mathrm{V}$ characteristic of organic solar cell varies with series resistance. It is concluded that at $1 \Omega$ series resistance, a smooth curve is found, at which maximum short circuit current as well as efficiency is obtained. It has been demonstrated by using different cathode contacts that high frequency resistance depend only on the active layer blend composition, and not on the outer contact structure. Therefore, it can be explained that the series resistance produces a remarkable effect on the $\mathrm{J}-\mathrm{V}$ characteristics of organic solar cell.

\section{Acknowledgements}

The authors sincerely thank the honorable Vice Chancellor, IFTM University, Moradabad for his support and encouragement to complete this research work.

\section{REFERENCES}

[1] N.S. Sariciftci, L. Smilowitz, A. J. Heeger, and F. Wudl., Photo induced electron transfer from a conducting polymer to bulkminsterfullerene. Science 258, 1474 (1992).

[2] A. Guerrero, T.R-Sanchis, P.P. Boix and G. G-Belmonte. Series resistance in organic bulk hetero junction solar device modulating carrier transport with fullerene electron traps. Organic Electronics 13, 2326-2332 (2012).

[3] G. Yu, J. Gao, J. C. Hummelen, F. Wudl, and A. J. Heeger. Optimization of conjugate-polymer based bulk hetero junction. Science 270, 1789 (1995).

[4] N. Rastogi, N. Singh, and M. Saxena, A brief review on current need of organic solar cells. International Journal of Innovative Research in Science, Engineering and Technology, $2,12,(2013)$.

[5] S. C. Jain, M. Willander, and V. Kumar, Conducting organic material and devices (Academic, San Diego, (2007).

[6] W. J. Belcher, K. I. Wagner, and P. C. Dastoor, The effect of porphyrin inclusion on the spectral response of ternaryP3HT: PCBM bulk hetero junction solar cells, Sol. Energy Mater. Sol. Cells 91 447-452 (2007).

[7] G. Yu, J. Gao, J. C. Hummelen, F. Wudl, and A. J. Heeger, Polymer photovoltaic cells: Enhanced efficiencies via a network of internal donor-acceptor hetero junctions, Science 270 1789-1791(1995).

[8] F. Padinger, R. S. Ritterberger, and N. S. Sariciftci, Effects of postproduction treatment on plastic solar cells, Adv. Funct. Mater. 13 85-88 (2003).

[9] Y. Kim, S. Cook, S. M. Tuladhar, S. A. Choulis, J. Nelson, J. R. Durrant, D. D. C. Bradley, M. Giles, I. McCulloch, C. S. Ha, and $\mathrm{M}$. Ree, A strong regioregularity effect in self-organizing conjugated polymer films and high-efficiency polythiophene fullerene solar cells, Nat. Mater. 5 197-203 (2006).

[10] J. Y. Kim, S. H. Kim, H. Lee, -H. K. Lee, W. Ma, X. Gong, and A. J. Heeger, New architecture for high-efficiency polymer photovoltaic cells using solution-based titanium oxide as an optical spacer, Adv. Mater. 18 572-576 (2006).

[11] G. Shrotriya, V. Li, J. Huang, Y. Yao, T. Moriarty, K. Emery, and Y. Yang, High-efficiency solution processable polymer photovoltaic cells by self-organization of polymer blends, Nat. Mater. 4 864-868 (2005).

[12] J. A. Hauch, P. Schilinsky, S. A. Choulis, R. Childers, M. Biele, and C. J. Brabec, Flexible organic P3HT:PCBM bulk-hetero junction modules with more than 1 year outdoor lifetime, Sol. Energy Mater. Sol. Cells 92 727-731 (2008)

[13] N. Rastogi, and N. Singh, Electrical simulation of organic solar cell at different series resistances and different device temperature. IOSR Journal of Applied Physics (IOSR-JAP).8, 54-57 (2016).

[14] S. H. Park, A. Roy, S. Beaupre, S. Cho, N. Coates, J.S. Moon, D. Moses, M. Leclerc, K. Lee, and A. J. Heeger, Bulk hetero junction solar cells with internal quantum efficiency approaching 100\%, Nature Photonics 3, 297-302 (2009).

[15] F.C. Krebs, S. Gevorgyan A. J. Alstrup, A roll-to-roll process to flexible polymer solar cells: model studies, manufacture and operational stability studies, Journal of Materials Chemistry 19, 5442-5451(2009).

[16] F. C. Krebs, et al., A round robin study of flexible large-area roll-to-roll processed polymer solar cell modules, Solar Energy Material and Solar Cells 93, 1968-1977 (2009)

[17] W. Ma, C. Yang, X. Gong, K. S. Lee, A. J. Heeger, Thermally stable, efficient polymer solar cells with nanoscale control of the interpenetrating network morphology, Advanced Functional Materials $15,1617-1622$ (2005).

[18] R. A. Street, K. W. Song, S.R. Cowan, Influence of series resistance the photocurrent analysis of organic solar cells, Org. Electron. 12, 244-248 (2011)

[19] S. R. Cowan, N. Banerji, W. L. Leong, A. J. Heeger, Charge formation, recombination, and sweep-out dynamics in organic solar cells, Adv. Funct. Mater. 22 1116-1128 (2012).

[20] S. H. Park, A. Roy, S. Beaupré, S. Cho, N. Coates, J. S. Coates, D. Moses, M. Leclerc, K. Lee, A. J. Heeger, Bulk hetero junction solar cells with internal quantum efficiency approaching 100\%, Nat. Photonics 3297-302 (2009)

[21] P.P. Boix, A. Guerrero, L.F. Marchesi. G.J. Garcia-Belmonte, Bisquert, Current-voltage characteristics of bulk hetero junction organic solar cells: connection between light and dark curves, Adv. Energy Mater 1, 1073-1078 (2011)

[22] T. Zhan, X. Shi, Y. Dai, X. Liu, and J. Zi, Journal of Physics: Condensed Matter, 252121530 (2013).

[23] N. Singh, A. Chaudhary, N. Rastogi of organic solar cell at different active layer thickness. International Journal of Material Science. 5, 2226-4523/15/01 022-5 2015.

[24] J.Yan, Handbook of Clean Energy Systems, https://books.google.co.in/books, 1118388585. Vol. 6 (2015). 